Review

\title{
Progress in Enzymatic Biodiesel Production and Commercialization
}

\author{
Liangliang Lv ${ }^{1}$, Lingmei Dai ${ }^{2}$, Wei Du ${ }^{1,2, *(\mathbb{D})}$ and Dehua Liu ${ }^{1,2, *}$ \\ 1 Tsinghua Innovation Center in Dongguang, Dongguang 523808, China; 111413@126.com \\ 2 Key Laboratory for Industrial Biocatalysis, Ministry of Education, Department of Chemical Engineering, \\ Tsinghua University, Beijing 100084, China; dailm@tsinghua.edu.cn \\ * Correspondence: author: duwei@tsinghua.edu.cn (W.D.); dhliu@tsinghua.edu.cn (D.L.)
}

\section{check for}

updates

Citation: Lv, L.; Dai, L.; Du, W.; Liu, D. Progress in Enzymatic Biodiesel Production and Commercialization. Processes 2021, 9, 355.

https://doi.org/10.3390/ pr9020355

Academic Editor: Lew P. Christopher Received: 24 December 2020

Accepted: 7 February 2021

Published: 15 February 2021

Publisher's Note: MDPI stays neutral with regard to jurisdictional claims in published maps and institutional affiliations.

Copyright: (c) 2021 by the authors. Licensee MDPI, Basel, Switzerland. This article is an open access article distributed under the terms and conditions of the Creative Commons Attribution (CC BY) license (https:// creativecommons.org/licenses/by/ $4.0 /)$.

\begin{abstract}
Enzymatic biodiesel production has attracted tremendous interest due to its well-recognized advantages. However, high enzyme costs limit the application of enzymatic processes in industrial production. In the past decade, great improvements have been achieved in the lab and the industrial scale, and the production cost of the enzymatic process has been reduced significantly, which has led to it being economically competitive compared to the chemical process. This paper summarizes the progress achieved in enzymatic biodiesel research and commercialization, including reducing enzyme cost, expanding low-quality raw materials, and novel reactor designs. The advantages and disadvantages of different enzymatic processes are also compared.
\end{abstract}

Keywords: biodiesel; lipase; oil feedstock; renewable energy; bioreactor

\section{Introduction}

Biodiesel has attracted great interest for its potential to relieve environmental pollution and the energy crisis [1]. In the last decade, biodiesel has attained a remarkable growth in industrial production and consumption worldwide. The European Union (EU) leads in biodiesel production, with 34\% of global production of nearly 41.2 million tons in 2018 (see Figure 1) [2].

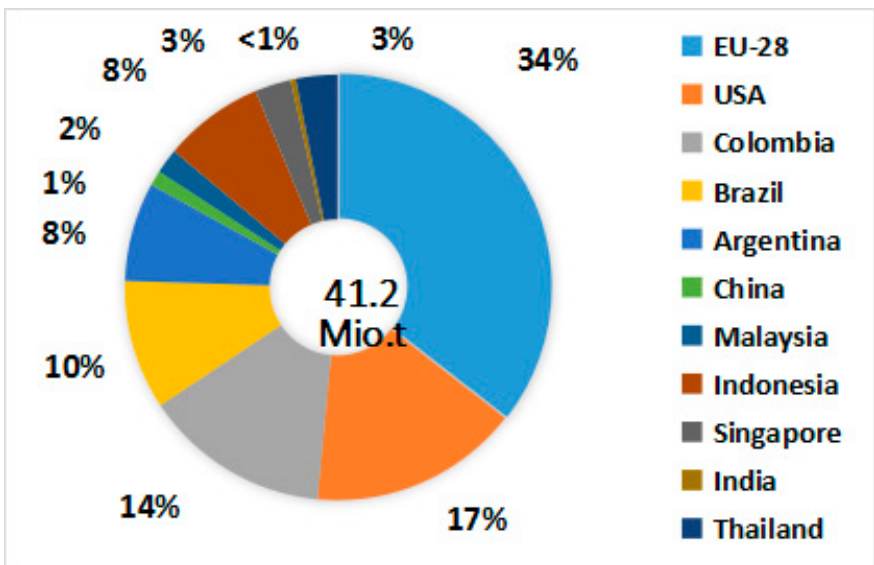

Figure 1. Biodiesel production contribution by different countries for the year 2018.

Generally speaking, biodiesel production is catalyzed by chemical catalysts at the industrial scale, especially alkaline-based catalysts. However, the conventional chemical process has the disadvantages of relatively high energy consumption, environmental pollution, difficulty in recovering the glycerol by-product, etc. Moreover, the chemical process has rather strict requirements on the content of free fatty acid and water contained in raw materials $[3,4]$. 
Compared to the conventional chemical process, lipase-mediated biodiesel production has well-recognized advantages, such as mild reaction conditions, easy product recovery, and environmental friendliness, and thus shows great prospect, especially when lowquality oils with high free fatty acid content are used as the feedstock [5-9]. However, only a few plants employ the enzymatic process for biodiesel production, and the biggest challenge for the enzymatic process is the high cost of lipase, which is used as the catalyst [10-12]. Research on developing new enzymes with a low price and high catalytic activity and stability has been one of the most important investigations to reduce enzyme cost [12]. Compared to the conventional alkali process, the biggest advantage of the enzymatic process is that it can efficiently use cheap and low-quality feedstocks with high free fatty acid content [10], which will significantly reduce the total production cost. Thus, expanding low-quality raw materials for the enzymatic process has great potential [10-12]. Another major challenge for the enzymatic process is to produce a final biodiesel product meeting standards [10-12]. Reactor design plays an important role in promoting esterification and transesterification reaction equilibria to realize the thorough conversion of oil feedstocks. This review introduces the progress achieved in the enzymatic biodiesel production process, mainly focusing on reducing enzyme cost, expanding low-quality raw materials, and novel reactor design.

\section{Improvement of the Enzymatic Biodiesel Production Process}

Lipase is widely used as a biocatalyst to catalyze hydrolysis and esterification and transesterification reactions. Although biodiesel preparation mediated by lipase has been extensively investigated, lipase cost is still relatively high compared to chemical catalysts, especially for immobilized lipase. Significant research has been conducted to reduce enzyme cost, such as exploring new lipase production from various microorganisms [13-15], lipase modification, and investigating improvements on lipase preparation [16,17]. Lipase has been successfully modified with enhanced catalytic activity and tolerance to both methanol and high temperatures through the use of advanced biotechnologies [18]. The performance of lipase, including catalytic activity and stability, is improved to a great extent by protein engineering and various enzyme immobilization approaches [19].

\subsection{Free Lipase-Catalyzed Process}

Over 60 species of microorganisms can produce lipase, such as Aspergillus oryzae, Rhizopus oryzae, Thermomyces lanuginosus, Candida antarctica, Pseudomonas cepacia, etc. [13-15]. A variety of lipases have been enhanced by protein design and directed evolution from different microorganisms to improve their thermoresistance and tolerance to methanol. Based on known structural 3D models of different lipases, the sites chosen for mutagenesis can be identified.

Lipase production includes strain improvement, fermentation culture, filtration, concentration and concocting, etc. Strain improvement and fermentation process optimization increase lipase production and directly reduce lipase cost. In the biodiesel production process, lipase concentration plays an important role. It was found that the yield increases with the increase of the enzyme dosage [20]. Membrane separation technology for lipase concentration has been studied and applied in the industry for years for its merits of high selectivity, simplicity, and energy savings in the process scale-up and operation [21-23]. The molecular weight of commercial lipase is about $20 \mathrm{kDa}-30 \mathrm{kDa}$, and the molecular weight of CalleraTM Trans L (CalT) is about $30 \mathrm{kDa}$, so ultrafiltration and nanofiltration separation are widely used [23]. Reinehr et al. [23] adopted ultrafiltration and microfiltration to concentrate lipase produced from Aspergillus niger. Wijiya et al. [24] used a sulfonated polyether sulfone nanofiltration membrane, with a molecular weight cut-off of $3 \mathrm{kDa}$, to concentrate lipase produced from recombinant $A$. oryzae. The total enzymatic activity increased at about fivefold after being separated by the membrane. The concentrated lipase from recombinant $A$. oryzae achieved a FAME (Fatty acid methyl ester) yield of $96.8 \%$ with unrefined palm oil as the feedstock. 


\subsection{Immobilized Lipase-Mediated Process}

Immobilized lipases show many advantages during the biodiesel production process, such as easier recovery and reuse, higher tolerance, greater $\mathrm{pH}$ and thermal stability etc. [25]. Compared to free enzymes, the immobilized lipase may improve the activity and stability of the lipase by modifying the protein's structure [26,27]. Materials such as silica, ceramics, carbon nanotubes, polymer resins, magnetic particles, and microspheres have been explored to immobilize lipases [28-31]. Various methods for lipase immobilization have been explored and generally, depending on the type of interactions between enzymes and carriers, these techniques can be classified into irreversible and reversible immobilization techniques [32]. Physical adsorption and non-covalent bonding are the most commonly used reversible immobilization technologies, including affinity bonding and chelation bonding, while cross-linking, entrapment, and covalent bonding are the most commonly used procedures for irreversible immobilization of lipases $[19,31,33]$.

The carrier is one of the key factors determining the catalytic efficiency and stability, as well as the cost, of the lipase. Different types of carriers have been extensively explored in recent years. Nanoscale materials have been the research and application hotspot for several years. The high surface-to-volume ratio makes these materials suitable for immobilizing proteins [34] One of the most promising candidates is nanofibrous membrane, which consists of many individual nanofibers fabricated using an electrospinning approach. Nanofibrous membrane has a high surface-to-volume ratio and space between the individual fibers with a low mass transfer resistance.

For immobilized lipase, a smaller-sized carrier can permit better exposure to the active sites but also causes problems in separating the lipase from the reaction mixture [35,36]. Using magnetic materials as lipase support helps to quickly separate the lipase by introducing external magnets with minimal mass loss. Furthermore, porous materials including silica, organic polymer, and carbon materials can be coated on the magnetic nanoparticles to improve chemical stabilities and also inhibit their aggregation [37,38]. Xie et al. [39] immobilized lipase on core-shell structured $\mathrm{Fe}_{3} \mathrm{O}_{4} @ \mathrm{MIL}-100(\mathrm{Fe})$ (MIL, Materials of Institute Lavoisier) composites for enzymatic biodiesel production. Through amide linkages, the $\mathrm{Fe}_{3} \mathrm{O}_{4}$ magnetite coated with porous MIL-100(Fe) metal-organic framework (MOF) material was adopted to immobilize lipase from Candida rugosa, and then the core-shell structured $\mathrm{Fe}_{3} \mathrm{O}_{4} @ \mathrm{MIL}-100(\mathrm{Fe})$ composites were synthesized. An immobilization efficiency of $83.1 \%$ was achieved with an enzymatic activity recovery of $63.5 \%$. Using an external magnetic field, the immobilized lipase could be facilely separated from the system. A biodiesel conversion yield of $92.3 \%$ was obtained, and $83.6 \%$ of the initial activity was displayed after being reused for five batches.

Although many technologies have been developed for lipase immobilization at the lab scale, only a few are industrialized due to the high cost of the immobilization process. The main challenge is the high cost of the carrier and the low efficiency of recovering proteins and retaining the enzymatic activity during the immobilization process. As the most widely reported immobilized lipase, Novozym 435 is sold at over $\$ 1000 / \mathrm{kg}$ [28]. An enzymatic biodiesel production line with a capacity of 20,000 t/y was built in China in 2006, in which a combination of different immobilized lipases was used as the catalyst with used cooking oil as the main feedstock [10]. Later, another lipase-mediated biodiesel production line was built with a capacity of 10,000 t/y, in which lipase from Candida sp. 99-125 was immobilized on textile membranes. The lipase cost was estimated to be only about $\$ 32 / t$ biodiesel (200 CNY/t biodiesel) [11]. In recent years, more immobilized lipase products specifically designed for biodiesel production have been developed, significantly reducing the price of lipase to about $\$ 150 / \mathrm{kg}$, which makes the use of enzymatic processes promising in practical production.

\subsection{Process Optimization for Enzyme Protection}

In addition to developing new lipases with new technologies and materials, process optimization for better protection and reutilization of lipase can significantly reduce lipase cost in practical production. Many factors affect lipase's catalytic activity, such as the type 
and concentration of acyl acceptor, the alcohol-to-oil ratio, the reaction medium, the water content, temperature, etc. Under optimized parameters, the enzymatic catalytic activity should remain stable in practical production.

A higher methanol concentration is beneficial for improving the biodiesel yield and the reaction rate. Theoretically, $3 \mathrm{~mol}$ of methanol is needed to completely convert $1 \mathrm{~mol}$ of glyceride, but for practical applications, the excess methanol is usually used to promote the reaction in the forward direction. Too much alcohol might seriously reduce the enzymatic activity, so a stepwise addition is usually performed to minimize the deactivation of the lipase, especially in a solvent-free system [11]. For free lipase, having the proper amount of water in the system will reduce the lipase deactivation caused by methanol. For immobilized lipase, the poor solubility of methanol in oil causes high local methanol concentration, which leads to enzyme deactivation. Both the methanol batch adding strategy and the organic medium system can eliminate methanol deactivation [40].

Water content significantly affects the biodiesel yield, the reaction rate as well as the enzyme's stability and activity. It is well recognized that, in a non-aqueous system, some amount of water is essential to maintain the enzyme's activity [41]. The availability of the interfacial area determines the lipase activity, and oil-water droplets cannot form at all in a water-free system [42]. However, too much water in the system will reduce the concentration of methanol and promote the hydrolysis of glyceride to generate free fatty acid. This subsequently reduces the biodiesel yield and the reaction rate to a great extent. It has been found that the optimal water content varies from a trace amount to about $20 \%$ in a solvent-free system, which is influenced by the lipase and oil feedstock $[43,44]$. Free lipase-catalyzed biodiesel production is performed in an oil/water two-phase system. Water also plays an important role in maintaining the activity of the free lipase, and it was found that water could significantly reduce the toxic effect of methanol on the enzyme's activity [45]. The essential amount of water needed to maintain the active conformation of enzyme molecules is only a few water molecules, and too much water may cause lipase agglomerate and proteins to drop off the carrier, resulting in a loss of the enzymatic activity [46].

The by-product glycerol has a comprehensive influence on lipase-mediated biodiesel production. Glycerol is likely to be absorbed on the surface of immobilized lipase, causing the lipase's catalytic activity to quickly drop [43]. Moreover, the by-product glycerol, with a rather high viscosity, may influence the diffusion of the reactant and subsequently influence the reaction rate. Washing with an organic solvent and using separation by membrane could eliminate the glycerol effect and extend the operational life of immobilized lipase [47]. However, it is not easy to apply the above-mentioned strategies into practical operations, especially at the industrial scale. For the free lipase-catalyzed biodiesel production process, too much glycerol accumulated in the system affects the reaction equilibrium, reducing conversion yield to a great extent.

In the optimized process, lipase catalytic activity remains stable after the reaction, making the reutilization of lipase practicable and necessary to reduce lipase cost in practical production. For free lipase-catalyzed biodiesel production, the oil phase and the water phase are easily separated by gravity or a centrifuge after the reaction. The water phase consists of water, glycerin, methanol, and lipase, and the lipase can be recycled using separation by membrane with proper pore size. For immobilized lipase-catalyzed biodiesel production, the lipase is easy to separate from the reactant. Due to the high price of immobilized lipase, the use of more reused batches is critical in practical production.

\section{Expanding Low-Quality Feedstocks}

One of the largest advantages of the enzymatic process is that cheap raw materials with a high content of free fatty acid and water can be adopted directly without complicated pre-treatment. Today, the main oil feedstock for biodiesel production in most countries is refined edible oil, such as refined rapeseed, soybean, and palm oil [48], and the cost of this oil feedstock accounts for more than $85 \%$ of the total production cost [49]. Expanding low- 
quality oil feedstock with a cheaper cost for biodiesel preparation has important economic significance. Low-quality raw materials may come from extensive sources, such as waste cooking oil, animal fat, and unrefined oils like crude palm oil and other plant or grassy oils [50].

Low-quality raw materials contain a relativity high content of fatty acid and water, resulting in a series of drawbacks for alkali-catalyzed biodiesel production. Free fatty acid will react with the alkaline catalyst to generate soap, which leads to difficulty in separating the final product, a lower conversion yield, and a higher catalyst consumption. Water in the system will hydrolyze triglyceride to produce fatty acid. Usually, fatty acid and water contents in the raw material should be respectively lower than $1.0 \%(w / w)$ and $0.1 \%$ $(w / w)$ for the alkaline-catalyzed process [47]. However, low-quality oils contain much more free fatty acid and water; for example, gutter oil usually contains more than $40 \%$ free fatty acid and $1 \%$ water. Herein, a complicated pre-treatment is usually needed for the alkaline-catalyzed process. Acid-mediated catalysis is insensitive to the content of FFA (Free fatty acid) present in the system, but the reaction speed is much slower than alkaline catalysis. Acid catalysis also has other drawbacks, such as a higher reaction temperature and corrosion to reactors. Heterogeneous acid catalysts were developed [51], such as carbon-based catalysts [52] and $\mathrm{Al}_{2} \mathrm{O}_{3}$-supported molybdenum oxide catalysts. However, no heterogeneous acid catalyst has been used in practical production, due to stability and cost issues.

Compared to chemical processes catalyzed by alkaline or acid, the enzymatic process is suitable for low-quality raw materials and has no strict requirement for free fatty acid and water content. The enzymatic process produces no soap, thereby achieving a higher conversion yield. Additionally, a better-quality glycerol without salt, and with much less wastewater, is produced, since no alkaline or acid is involved in the process. Low-quality raw materials can be used directly without complicated pre-treatment. For example, the chemical process uses refined palm oil, subjected to a degumming and bleaching process, as a raw material, but the enzymatic process can directly use crude palm oil as a raw material.

For crude soybean oil, the presence of phospholipids causes problems for alkaline biodiesel production, reducing the conversion yield [53]. As the content of phospholipids exceeds 50 ppm, the biodiesel conversion yield drops by 3-5\% [54]. The content of phospholipids contained in crude soybean oils usually varies from $0.5 \%$ to $3 \%(w / w)$ [55]. For the free lipase-catalyzed biodiesel production process, the presence of even a small amount of phospholipids can enhance the reaction rate. Li et al. used free lipase NS81006 to catalyze soybean oil containing different contents of phospholipids and found that as the phospholipid content increased from $0.2 \%$ to $2 \%(w / w)$, with low content of phospholipid present in the system, the reaction rate was improved, however, when the phospholipid content exceeded 5\%, the reaction rate decreased [56]. Furthermore, lipase can catalyze phospholipids to generate free fatty acid and phosphorous-contained products [57,58], and the latter mainly concentrate in the water phase. As the phospholipid content in the raw material is less than $2 \%(w / w)$, the phosphorus content in the oil phase meets the EN14214 requirement [59]. It is reported that during the immobilized lipase-mediated biodiesel preparation process, the presence of phospholipids restrains the reaction to a great extent $[60,61]$.

\section{Novel Reactor Design for Biodiesel Production}

Different types of reactors, such as packed-bed reactors (PBRs), fluidized-bed reactors (FBRs), bubble column reactors (BCRs), stirred-tank reactors (STRs), or a combination of multiple reactors, are commonly used for biodiesel production [62]. The type of catalyst and oil feedstock influences the selection of reactor in practical production. An STR can achieve a high conversion yield for its well-mixed quality [63]. However, a high impeller shearing force would cause enzyme drop from the carrier, and the impeller may even deactivate the enzyme due to the high-speed rotation, leading to a poor reusability of the 
catalyst [11]. It was found that the activity of Novozym 435 could retain $95 \%, 70 \%$, and $41 \%$, respectively, after being used for 5 batches, 8 batches, and 11 batches [64].

The PBR is a promising reactor for biodiesel production, especially for large-scale application, because it can obtain a larger reacting surface area per unit volume $[63,65]$. The key part is a column in which the immobilized enzyme is packed, and no impeller exists in the reactor. Compared to an STR, damage to the enzyme is largely reduced. Using the methanol stepwise addition and removal of glycerol strategy, the conversion yield can maintain over $95 \%$ during 108 days of operation [66]. However, the small size of the enzyme carrier and high viscosity of the reaction mixture causes a high pressure drop in the catalyst bed, especially when obstructed by impurities from the reaction mixture [25]. Furthermore, bad mass transfer limits the reaction rate and biodiesel conversion yield because the flow velocity inside the PBR is limited due to the pressure drop allowance [25,62].

The airlift loop reactor (ALR) is also a promising reactor for enzymatic biodiesel production. The ALR has a separate channel for the downflow and a rising channel for the gas-liquid upflow [67]. The gas is injected from the bottom of the rising channel to mix the immobilized lipase and reactants well, and to push the reactants upward in the rising channel and downward in the downflow channel. A novel airlift loop reactor without external gas is developed [68]. The internal gas at the top of the reactor (mainly vapor of the reactants) is recycled, and the reactants are well-mixed with the immobilized lipase. Thus, an ALR can largely reduce energy consumption and protect enzymes from mechanical damage.

Reactor design is important for enzymatic biodiesel production at the industrial scale. Extensive research has been carried out to improve the productivity and reduce the running cost of enzymes by strengthening mass transfer and minimizing mechanical damage to the enzyme. However, improvement is still needed to remove the negative effects caused by glycerin and excess water, since glycerin and water present in the system have a great influence on the catalytic activity and reusability of the enzyme. Additionally, they are the key factors to make the final product qualified by promoting the reaction equilibrium to a forward reaction. Some separation units, including extraction, adsorption, and membrane separation, have been combined with conventional reactors $[69,70]$. The modification also increases the complexity of the reactors and the production cost, to some extent, and this needs to be taken into consideration.

\section{Comparison between Different Enzymatic Processes}

Today, enzymatic processes already applied in industral or pilot-scale production include the immobilized lipase process, the immobilized lipase process with organic solvent, the free lipase process, and the combined process of free and immobilized lipase.

Immobilized lipase process: Using immobilized lipase for biodiesel preparation shows great prospect for the easier recovery of the enzyme. However, glycerin will absorb on the surface of immobilized lipase. For crude oils, like soybean oil, phospholipids will also absorb on the surface of lipase, which will reduce catalytic activity [60,61]. Moreover, the poor solubility of methanol in oil causes high local methanol concentration, which leads to enzyme deactivation. Considering the high price of immobilized lipase, the key challenge is the protection of lipase.

Immobilized lipase process with organic solvent: Organic solvents, like tert-butanol, could protect lipase by dissolving methanol, glycerin, or phospholipids to form a homogeneous system. Lipase catalytic activity loss caused by high local methanol concentration and adsorption of glycerin or phospholipids is solved in this process. However, the loss of solvent in the reutilization process and the separation of solvent both increase the production cost. Some solvents, like tert-butanol, will form an azeotrope system with water, leading to a high energy consumption to separate the water from the solvent.

Free lipase process: Characterized as a simple process and fast reaction rate, free lipasecatalyzed biodiesel production has drawn increasing attention [71,72]. Furthermore, the cost of free lipase is much lower than that of immobilized lipase, and the lipase reutilization 
process makes the lipase cost low. However, biodiesel specifications after the free lipasecatalyzed reaction cannot meet the requirements; for example, the acid value is usually higher than $2 \mathrm{mg} \mathrm{KOH} / \mathrm{g}$ due to the existence of water in the system. To make the qualified specifications, one solution existing on the market is to remove fatty acid by adding alkaline, which leads to a low conversion yield, especially with low-quality oils as raw materials. Making product specifications meet the requirements after the free lipase process is the key challenge.

Combined utilization of immobilized lipase and free lipase: The free lipase process followed by the immobilized process is a solution to make the biodiesel product qualified. Hydrolysis and esterification and transesterification reactions mainly occur in the free lipase process. Meanwhile, phospholipids will be degraded, and phosphorus and glycerin will concentrate in the water phase [57-59]. The oil phase and the water phase are separated by gravity or a centrifuge, and only the oil phase, containing some amount of free fatty acids, very little water, monoglycerides, and diglycerides, goes to the immobilized lipase process; thus, immobilized lipase activity loss caused by glycerin or phospholipids is successfully avoided. During the immobilized lipase process, fatty acid is converted into FAMEs, and a water by-product is generated. To realize the thorough conversion of free fatty acid to meet the related specification, on-line water removal is significant for the immobilized lipase process. When this is achieved successfully, the final fatty acid content is reduced below $0.25 \%$ in a novel air-lift reactor without external gas input. Meanwhile, lipase activity loss caused by stirring shear is avoided, and the immobilized lipase can be reused for more than 100 batches [68].

\section{Conclusions}

Due to their well-recognized merits including environmental friendliness, mild reaction conditions, and wide adaptability for feedstocks, enzymatic processes show great prospect for biodiesel production. Great progress has been made to reduce the whole cost of biodiesel production by reducing enzyme production cost, expanding low-quality raw materials, and designing novel reactors.

Several enzymatic processes with different features have been applied in industral or pilot-scale production. The combined utilization of free and immobilized lipase is promising, especially when the high-quality biodiesel product as well as the lack of alkali/acid wastewater discharge in the whole process is taken into consideration.

Author Contributions: Paper preparation, L.L.; Paper outline suggestion \& modification, L.D., D.L. and W.D. All authors have read and agreed to the published version of the manuscript.

Funding: The authors express their gratitude to the support from Dongguan Science \& Technology Bureau (Innovative R\&D Team Leadership of Dongguan City, 201536000100033).

Acknowledgments: The authors express their gratitude to the support from China-Latin America Joint Laboratory for Clean Energy and Climate Change (KY201501004), and Dongguan Science \& Technology Bureau (Innovative R\&D Team Leadership of Dongguan City, 201536000100033).

Conflicts of Interest: The authors declare no conflict of interest.

\section{References}

1. Ullah, F.; Dong, L.S.; Bano, A.; Peng, Q.Q.; Huang, J. Current advances in catalysis toward sustainable biodiesel production. J. Energy Inst. 2016, 89, 282-292. [CrossRef]

2. Li, Y.; Du, W.; Dai, L.M.; Liu, D.H. Kinetic study on free lipase NS81006-catalyzed biodiesel production from soybean oil. J. Mol. Catal. B Enzym. 2015, 121, 22-27. [CrossRef]

3. Brunschwig, C.; Moussavou, W.; Blin, J. Use of bioethanol for biodiesel production. Prog. Energy Combust. 2012, 38, $283-301$. [CrossRef]

4. Li, Y.; Du, W.; Liu, D.H. Efficient biodiesel production from phospholipids-containing oil: Synchronous catalysis with phospholipase and lipase. Biochem. Eng. J. 2015, 94, 45-49. [CrossRef]

5. Nassereldeen, A.K.; Nurudeen, I.M.; Md, Z.A. Hydrolysis of Jatropha curcas oil for biodiesel synthesis using immobilized Candida cylindracea lipase. J. Mol. Catal. B Enzym. 2015, 116, 95-100. 
6. Tian, X.G.; Dai, L.M.; Liu, M.S. Lipase-catalyzed methanolysis of Minsheng microalgae oil for biodiesel production and PUFAs concentration. Catal. Commun. 2016, 84, 44-47. [CrossRef]

7. Su, F.; Li, G.L.; Fan, Y.L.; Yan, Y.J. Enhancing biodiesel production via a synergic effect between immobilized Rhizopus oryzae lipase and Novozym 435. Fuel Process. Technol. 2015, 137, 298-304. [CrossRef]

8. Stanislav, V.V.; Christina, G.V. Composition, properties and challenges of algae biomass for biofuel application: An overview. Fuel 2016, 181, 1-33.

9. Kírian, B.R.; Canet, A.; Benaiges, M.D.; Valero, F. Synthesis of biodiesel from high FFA alperujo oil catalysed by immobilised lipase. Fuel 2015, 161, 12-17.

10. Du, W.; Li, W.; Sun, T.; Chen, X.; Liu, D. Perspectives for biotechnological production of biodiesel and impacts. Appl. Microbiol. Biotechnol. 2008, 79, 331-337. [CrossRef]

11. Tan, T.; Lu, J.; Nie, K.; Deng, L.; Wang, F. Biodiesel production with immobilized lipase: A review. Biotechnol. Adv. 2010, 28, 628-634. [CrossRef] [PubMed]

12. Vyas, A.P.; Verma, J.L.; Subrahmanyam, N. A review on fame production processes. Fuel 2010, 89, 1-9. [CrossRef]

13. Narwal, S.K.; Gupta, R. Biodiesel production by transesterification using immobilized lipase. Biotechnol. Lett. 2013, 35, 479-490. [CrossRef]

14. Hama, S.; Noda, H.; Kondo, A. How lipase technology contributes to evolution of biodiesel production using multiple feedstocks. Curr. Opin. Biotechnol. 2018, 50, 57-64. [CrossRef] [PubMed]

15. Bajaj, A.; Lohan, P.; Jha, P.N.; Mehrotra, R. Biodiesel production through lipase catalyzed transesterification: An overview. J. Mol. Catal. B Enzym. 2010, 62, 9-14. [CrossRef]

16. Sasaki, K.; Tsuge, Y.; Sasaki, D.; Teramura, H.; Inokuma, K.; Hasunuma, T.; Ogino, C.; Kondo, A. Mechanical milling and membrane separation for increased ethanol production during simultaneous saccharification and co-fermentation of rice straw by xylose-fermenting Saccharomyces cerevisiae. Bioresour. Technol. 2015, 185, 263-268. [CrossRef]

17. Febriani; Hertadi, R.; Kahar, P.; Akhmaloka; Madayanti, F. Isolation and purification of novel thermostable alkaline lipase from local thermophilic microorganism. Biosci. Biotechnol. Res. Asia 2010, 7, 617-622.

18. Hwang, H.T.; Qi, F.; Yuan, C.; Zhao, X.; Ramkrishma, D.; Liu, D. Lipase-catalyzed process for biodiesel production: Protein engineering and lipase production. Biotechnol. Bioeng. 2014, 111, 639-653.

19. Cao, L. Carrier-Bound Immobilized Enzymes: Principles, Application and Design, 1st ed.; Wiley-VCH Verlag GmbH \& Co. KGaA: Weinheim, Germany, 2005.

20. He, Q.; Xu, Y.; Teng, Y.; Wang, D. Biodiesel Production Catalyzed by Whole-Cell Lipase from Rhizopus chinensis. Chin. J. Catal. 2008, 29, 41-46. [CrossRef]

21. Menoncin, S.; Domingues, N.M.; Freire, D.M.G.; Toniazzo, G.; Cansian, R.L.; Oliveira, J.V.; Di Luccio, M.; de Oliveira, D.; Treichel, H. Study of the extraction, concentration, and partial characterization Menoncin of lipases obtained from Penicillium verrucosum using solid-state fermentation of soybean bran. Food Bioprocess. Technol. 2010, 3, 537-544. [CrossRef]

22. Preczeski, K.P.; Kamanski, A.B.; Scapini, T.; Camargo, A.F.; Modkoski, T.A.; Rossetto, V.; Venturin, B.; Mulinari, J.; Golunski, S.M.; Mossi, A.J.; et al. Efficient and low-cost alternative of lipase concentration aiming at the application in the treatment of waste cooking oils. Bioprocess Biosyst. Eng. 2018, 41, 851-857. [CrossRef]

23. Reinehr, C.O.; Treichel, H.; Tres, M.V.; Steffens, J.; Brião, V.B.; Colla, L.M. Successive membrane separation processes simplify concentration of lipases produced by Aspergillus niger by solid-state fermentation. Bioprocess Biosyst. Eng. 2017, 40, 843-855. [CrossRef]

24. Wijaya, H.; Sasaki, K.; Kahar, P.; Quayson, E.; Rachmadona, N.; Amoah, J.; Hama, S.; Ogino, C.; Kondo, A. Concentration of Lipase from Aspergillus oryzae Expressing Fusarium heterosporum by Nanofiltration to Enhance Transesterification. Process 2020, 8, 450. [CrossRef]

25. Öztürk, B. Immobilization of Lipase from Candida Rugosa on Hydrophobic and Hydrophilic Supports. Master's Thesis, İzmir Institute of Technology, İzmir, Turkey, 2001.

26. Amini, Z.; Ilham, Z.; Ong, H.C.; Mazaheri, H.; Chen, W.H. State of the art and prospective of lipase-catalyzed transesterification reaction for biodiesel production. Energy Convers. Manag. 2016, 141, 339-353. [CrossRef]

27. Xie, W.; Wang, J. Enzymatic production of biodiesel from soybean oil by using immobilized lipase on $\mathrm{Fe}_{3} \mathrm{O}_{4} / \mathrm{poly}(\mathrm{styrene-}$ methacrylic acid) magnetic microsphere as a biocatalyst. Energy Fuel 2014, 28, 2624-2631. [CrossRef]

28. Stoytcheva, M.; Monstero, G.; Toscano, L.; Gochev, V.; Valdez, B. The immobilized lipases in biodiesel production. In BiodieselFeedstocks and Processing Technologies; Stoytcheva, M., Ed.; InTech.: Rijeka, Croatia, 2011; pp. 397-410.

29. Tan, H.; Feng, W.; Ji, P. Lipase immobilized on magnetic multi-walled carbon nanotubes. Bioresour. Technol. 2012, 115, 172-176. [CrossRef]

30. Ren, Y.; Rivera, J.G.; He, L.; Kulkarni, H.; Lee, D.K.; Messersmith, P.B. Facile, high efficiency immobilization of lipase enzyme on magnetic iron oxide nanoparticles via a biomimetic coating. BMC Biotechnol. 2011, 11, 63. [CrossRef]

31. Zhang, D.H.; Yuwen, L.X.; Xie, Y.L.; Li, W.; Li, X.B. Improving immobilization of lipase onto magnetic microspheres with moderate hydrophobicity/hydrophilicity. Colloids Surf. B Biointerfaces 2012, 89, 73-78. [CrossRef]

32. Brena, B.M.; Batista-Viera, F. Immobilization of enzymes. In Methods in Biotechnology: Immobilization of Enzymes and Cells; Guisan, J.M., Ed.; Humana Press Inc.: New York, NY, USA, 2006; pp. 15-30. 
33. Zhang, B.; Weng, Y.; Xu, H.; Mao, Z. Enzyme immobilization for biodiesel production. Appl. Microbiol. Biotechnol. $2012,93,61-70$. [CrossRef] [PubMed]

34. Long, Y.Z.; Li, M.M.; Gu, C.Z.; Wan, M.X.; Jean-Luc, D.; Liu, Z.W.; Fan, Z.Y. Recent advances in synthesis, physical properties and applications of conducting polymer nanotubes and nanofibers. Progress Polym. Sci. 2011, 36, 1415-1442. [CrossRef]

35. Cipolatti, E.P.; Valério, A.; Henriques, R.O.; Moritz, D.E.; Ninow, J.L.; Manoel, E.A.; Freire, D.M.G.; Lafuente, R.F.; Oliveire, D. Nanomaterials for biocatalyst immobilization-state of the art and future trends. RSC Adv. 2016, 6, 104675-104692. [CrossRef]

36. Bonet-Ragel, K.; López-Pou, L.; Tutusaus, G.; Benaiges, M.D.; Valero, F. Rice husk ash as a potential carrier for the immobilization of lipases applied in the enzymatic production of biodiesel. Biocatal. Biotransform. 2018, 36, 151-158. [CrossRef]

37. Miao, C.; Yang, L.; Wang, Z.; Luo, W.; Li, H.; Lv, P.; Yuan, Z. Lipase immobilization on amino-silane modified superparamagnetic $\mathrm{Fe}_{3} \mathrm{O}_{4}$ nanoparticles as biocatalyst for biodiesel production. Fuel 2018, 224, 774-782. [CrossRef]

38. Xie, W.; Han, Y.; Wang, H. Magnetic $\mathrm{Fe}_{3} \mathrm{O}_{4} / \mathrm{MCM}-41$ composite-supported sodium silicate as heterogeneous catalysts for biodiesel production. Renew. Energy 2018, 125, 675-681. [CrossRef]

39. Xie, W.L.; Huang, M.Y. Enzymatic Production of Biodiesel Using Immobilized Lipase on Core-Shell Structured Fe $\mathrm{O}_{4} @ \mathrm{MIL}^{-100(F e)}$ Composites. Catalysts 2019, 9, 850. [CrossRef]

40. Wang, L.Y.; He, H.Y.; Xie, Z.F. Transesterification of the crude oil of rapeseed with $\mathrm{NaOH}$ in supercritical and subcritical methanol. Fuel Process. Technol. 2007, 88, 477-481. [CrossRef]

41. Lu, J.; Chen, Y.; Wang, F.; Tan, T. Effect of water on methanolysis of glycerol trioleate catalyzed by immobilized lipase Candida sp. 99-125 in organic solvent system. J. Mol. Catal. B Enzym. 2009, 56, 122-125. [CrossRef]

42. Noureddini, H.; Gao, X.; Philkana, R.S. Immobilized Pseudomonas cepacia lipase for biodiesel fuel production from soybean oil. Bioresour. Technol. 2005, 96, 769-777. [CrossRef]

43. Kawakami, K.; Oda, Y.; Takahashi, R. Application of a Burkholderia cepacia lipase-immobilized silica monolith to batch and continuous biodiesel production with a stoichiometric mixture of methanol and crude Jatropha Oil. Biotechnol. Biofuels 2011, 4, 42. [CrossRef]

44. Dhake, K.P.; Bhatte, K.D.; Wagh, Y.S.; Singhal, R.S.; Bhanage, B.M. Immobilization of steapsin lipase on macroporous immobead350 for biodiesel production in solvent free system. Biotechnol. Bioprocess Eng. 2012, 17, 959-965. [CrossRef]

45. Kaieda, M.; Samukawa, T.; Kondo, A.; Fukuda, H. Effect of methanol and water contents on production of biodiesel fuel from plant oil catalyzed by various lipases in a solvent-free system. J. Biosci. Bioeng. 2001, 91, 12-15. [CrossRef]

46. Laane, C.; Boeren, S.; Vos, K.; Veeger, C. Rules for optimization of biocatalysis in organic solvents. Biotechnol. Bioeng. 1987, 30, 81-87. [CrossRef]

47. Bélafi-bakó, K.; Kovács, F.; Gubicza, L.; Hancsók, J. Enzymatic biodiesel production from sunflower oil by Candida antarctica lipase in a solvent-free system. Biocatal. Biotransform. 2002, 20, 437-439. [CrossRef]

48. Hama, S.; Kondo, A. Enzymatic biodiesel production: An overview of potential feedstocks and process development. Bioresour. Technol. 2013, 135, 386-395. [CrossRef] [PubMed]

49. Moser, B.R. Influence of blending canola, palm, soybean, and sunflower oil methyl esters on fuel properties of biodiesel. Energy Fuels 2008, 22, 4301-4306. [CrossRef]

50. Encinar, J.M.; Sanchez, N.; Martinez, G.; Garcia, L. Study of biodiesel production from animal fats with high free fatty acid content. Bioresour. Technol. 2011, 102, 10907-10914. [CrossRef] [PubMed]

51. Mahlia, T.M.I.; Syazmi, Z.; Mofijur, M.; Abas, A.E.P.; Bilad, M.R.; Ong, H.C.; Silitonga, A.S. Patent landscape review on biodiesel production: Technology updates. Renew. Sustain. Energy Rev. 2020, 118, 9. [CrossRef]

52. Lou, W.Y.; Zong, M.H.; Duan, Z.-Q. Efficient production of biodiesel from high free fatty acid-containing waste oils using various carbohydrate-derived solid acid catalysts. Bioresour. Technol. 2008, 99, 8752-8758. [CrossRef] [PubMed]

53. Freedman, B.; Pryde, E.H.; Mounts, T.L. Variables affecting the yields of fatty esters from transesterified vegetable-oils. J. Am. Oil Chem. Soc. 1984, 61, 1638-1643. [CrossRef]

54. Gerpen JH, V.; Dvorak, B. The effect of phosphorus level on the total glycerol and reaction yield of biodiesel. In Proceedings of the The 10th Biennial Bioenergy Conference, Boise, ID, USA, 22-26 September 2002.

55. Cowan, D.; Nielsen, P.M. Enzymatic degumming of edible oils and fats. In Bleaching and Purifying Fats and Oils: Theory and Practice; Patterson, H.B.W., Ed.; AOCS Press: Urbana, IL, USA, 2009; pp. 216-235.

56. Li, Y.; Du, W.; Liu, D. Exploration on the effect of phospholipids on free lipase-mediated biodiesel production. J. Mol. Catal. B-Enzym. 2014, 102, 88-93. [CrossRef]

57. Li, W.; Du, W.; Liu, D. Rhizopus oryzae IFO 4697 whole cell catalyzed methanolysis of crude and acidified rapeseed oils for biodiesel production in tert-butanol system. Process Biochem. 2007, 42, 1481-1485. [CrossRef]

58. Yang, L. Study on the Effect of Phospholipids on Free Lipase-Mediated Methanolysis for Biodiesel Production. Ph.D. Thesis, Tsinghua Univerisity, Beijing, China, 2015.

59. Balasubramanian, R.K.; Obbard, J.P. Heterogeneous catalytic transesterification of phosphatidylcholine. Bioresour. Technol. 2011, 102, 1942-1946. [CrossRef] [PubMed]

60. Amoah, J.; Ho, S.; Hama, S.; Yoshida, A.; Nakanishi, A.; Hasunuma, T.; Ogino, C.; Kondo, A. Converting oils high in phospholipids to biodiesel using immobilized Aspergillus oryzae whole-cell biocatalysts expressing Fusarium heterosporum lipase. Biochem. Eng. J. 2016, 105, 10-15. [CrossRef] 
61. Du, W.; Xu, Y.Y.; Zeng, J.; Liu, D. Novozym 435-catalysed transesterification of crude soya bean oils for biodiesel production in a solvent-free medium. Biotechnol. Appl. Biochem. 2004, 40, 187-190.

62. Han, J.Y.; Kim, H.K. Transesterification using the cross-linked enzyme aggregate of Photobacterium lipolyticum lipase M37. J. Microbiol. Biotechnol. 2011, 21, 1159-1165. [CrossRef]

63. Balcáo, V.M.; Paiva, A.L.; Malcata, F.X. Bioreactors with immobilized lipases: State of the art. Enzym. Microb. Technol. 1996, 18, 392-416. [CrossRef]

64. Sanches, F.; Vasudevan, P.T. Enzyme catalyzed production of biodiesel from olive oil. Appl. Biochem. Biotechnol. 2006, 135, 1-14. [CrossRef]

65. Xu, Y. Process Technology for Immobilized Lipase Catalyzed Reactions. Ph.D. Thesis, Technical University of Denmark, Lyngby, Denmark, 2012.

66. Ognjanovic, N.; Bezbradica, D.; Knezevic-Jugovic, Z. Enzymatic conversion of sunflower oil to biodiesel in a solvent-free system: Process optimization and the immobilized system stability. Bioresour. Technol. 2009, 100, 5146-5154. [CrossRef]

67. Merchuk, J.C.; Gluz, M. Bioreactors, Air Lift Reactors; Wiley Online Library: Hoboken, NJ, USA, 2002; pp. $320-352$.

68. Du, W.; Li, L.; Liu, D. Airlift Circumfluent Reactor Needing No Foreign Air Source. WO 2006122498, 17 May 2006.

69. Dussan, K.; Cardona, C.; Giraldo, O.; Gutiérrez, L.; Pérez, V. Analysis of a reactive extraction process for biodiesel production using a lipase immobilized on magnetic nanostructures. Bioresour. Technol. 2010, 101, 9542-9549. [CrossRef] [PubMed]

70. Chesterfield, D.M.; Rogers, P.L.; Al-Zani, E.O.; Adesina, A.A. A novel continuous extractive reactor for biodiesel production using lipolytic enzyme. Procedia Eng. 2012, 49, 373-383. [CrossRef]

71. Leung, D.Y.C.; Wu, X.; Leung, M.K.H. A review on biodiesel production using catalyzed transesterification. Appl. Energy 2010, 87, 1083-1095. [CrossRef]

72. Lin, L.; Zhou, C.S.; Vittayapadung, S.; Shen, X.; Dong, M. Opportunities and challenges for biodiesel fuel. Appl. Energy 2011, 88, 1020-1031. [CrossRef] 